\title{
Technology Implementation: Its opportunities and Challenges Perceived by EFL Students
}

\author{
Abdul Gafur Marzuki \\ IAIN Palu \\ gbudiperwira@gmail.com \\ Santiana \\ Universitas Siliwangi \\ santiana@siliwangi.ac.id
}

\begin{abstract}
This examination targets breaking down the using of innovation in upgrading English language learning at the tertiary level. The examination utilized a subjective plan. An overview was utilized for information assortment in which 50 college understudies from three distinct classes in Palu city revealed having occupied with EFL getting the hang of utilizing YouTube, Kahoot (advanced games), and video recording. The information were gathered from the poll and meeting of each class. The outcomes show that the utilization of innovation in EFL learning gives advantages to improve understudies' insight and language learning results with regards to regular daily existence. Understudies show positive learning results and reactions to the utilization of innovation utilized in language learning.

\section{Introduction}

Consolidating innovation into the instructing and learning interaction can help understudies' dynamic commitment with learning. It establishes another learning climate to improve class participation and arrangement just as understudies' dynamic interest during class. Numerous specialists have featured the purposes behind coordinating innovation in educating and learning exercises which are 1) to assist understudies with setting up their future professions, 2) to arrive at the variety in learning style, 3) to allows understudies to communicate with their cohorts more by empowering cooperation, and 4) to assists the instructors with planning understudies for this present reality climate. Notwithstanding, there are huge difficulties in executing the innovation. One of them, speaker isn't acclimated with utilizing learning frameworks that are totally on the web or online premise. Challenges emerge in light of the fact that they have not used to hardware for virtual learning models.
\end{abstract}

\section{Research Methodology}

This exploration utilizes a subjective overview. The general motivation behind the study is to acquire a preview of understudies' learning experience conditions, mentalities, or 
potentially occasions of a whole populace at a solitary point on schedule by gathering information from an example drawn from that populace (Bailey, 2009). Interest in this investigation was restricted to University understudies who joined up with General English Subject utilizing innovation (YouTube, Kahoot (Digital Games), and Video Recording. The finished reaction was acquired from 50 understudies from three distinct classes. The review utilized a survey that comprised of 15 inquiries to evoke data on the instructional plan of utilizing innovation and its benefit in building up understudies' language abilities.

\section{Findings and Discussion}

The discoveries in this examination show that the utilization of innovation in EFL learning offers the advantage to improve understudies' language learning experience with rehearsing the language in a genuine setting. It likewise demonstrates that the instructional plan of utilizing a solitary piece of innovation as an instructional language educating and learning apparatus enormously affects understudies' commitment with language learning. The consequence of the investigation shows that engaging web-based media like YouTube and make a conversation utilizing questionable proclamations assist understudies with taking an interest in the conversation. The outcome likewise shows that the understudies are all around took part in portraying any occasion or recordings posting on YouTube by the Lecturer. Also, the discoveries from utilizing Kahoot as advanced games and video recording help understudies improving their commitment with EFL discovering that brought about upgrading their language abilities. Such engaging gives language inputs that assist them with creating proper language in correspondence. Understudies in this examination guarantee that computerized games assist them with advancing their jargon. Accordingly, they additionally guarantee that utilizing advanced video recording assists them with depicting right elocution, sound, and word pressure.

\section{Conclusion}

The execution of innovation in learning English has urged EFL teachers to augment the learning interaction by utilizing different mechanical assets. This examination centers around the chances and difficulties of the utilization of innovation as a medium in the learning cycle, to be specific YouTube, Kahoot (computerized game), and video recording. The outcomes show that the utilization of innovation in EFL learning gives advantages to improve understudies' insight and language learning results with regards to regular daily existence. In the first place, YouTube gives advantages to understudies to have the option to communicate assessments, examine, and contend, second, Kahoot (advanced games) upholds understudies to enhance their jargon and language articulations, and voice recording permits understudies to improve their elocution, pitch, and word pressure. Therefore, understudies show positive learning results and reactions to the utilization of innovation utilized in language learning. 


\section{References}

Ahmad, J. (2012). English language teaching (ELT) and integration of media technology. Procedia-Social and Behavioral Sciences, 47, 924-929.

Chan, W. M., Chin, K. N., Nagami, M., \& Suthiwan, T. (Eds.). (2011). Media in foreign language teaching and learning (Vol. 5). Walter de Gruyter.

Chapelle, C. (2003). English language learning and technology. John Benjamins Publishing Company.

Cummins, J., \& Davison, C. (Eds.). (2007). International handbook of English language teaching (Vol. 15). Springer Science \& Business Media.

Grigoryeva, E. V., Leyfa, I. I., Yatsevich, L. P., Demyanenko, M. A., Makovey, N. V., Pavlushkina, T. V., \& Masalimova, A. R. (2015). Designing technology of English language teaching content based on international component. Rev. Eur. Stud., 7, 123.

Hamadeh, W., Bahous, R., Diab, R., \& Nabhani, M. (2020). Using Social Media to Enhance Second Language Learning. Computer-Assisted Language Learning Electronic Journal, 21(2), 132-149.

Kessler, G. (2018). Technology and the future of language teaching. Foreign language annals, 51(1), 205-218.

Lamy, M. N., \& Mangenot, F. (2013). Social media-based language learning: insights from research and practice. In Social networking for language education (pp. 197-213). Palgrave Macmillan, London.

Marzuki, A. G. (2019). The Implementation of SQ3R Method to Develop Students' Reading Skill on Islamic Texts in EFL Class in Indonesia. Register Journal, 12(1), 49-61.

Marzuki, A.G. (2016). Utilizing cooperative learning in islamic college students' classroom, IJEE (Indonesian Journal of English Education), 3(2), 123-139.

Marzuki, A.G. (2017). Developing speaking skill through oral report in an efl class in indonesia, Al-Ta'lim Journal, 24(3), 243-254.

Murray, D. E. (2007). Creating a technology-rich English language learning environment. In International handbook of English language teaching (pp. 747-762). Springer, Boston, MA.

Rodinadze, S., \& Zarbazoia, K. (2012). The advantages of information technology in teaching English language. Frontiers of Language and Teaching, 3(5), 271-275.

Santiana, S., \& Fatimah, A. S. (2017). Prezi, Cloud-Based Presentation, for Teaching: How is it Interesting?. EduLite: Journal of English Education, Literature and Culture, 2(2), 445-456.

Stockwell, G. (2013). Technology and motivation in English-language teaching and learning. In International perspectives on motivation (pp. 156-175). Palgrave Macmillan, London.

Thorne, S. L. (2010). The "intercultural turn" and language learning in the crucible of new media. Telecollaboration, 2, 139-164. 